スノデ．刎論え八「レ」線「キモグラフィー」 全體二亘\%テ必要ナコトデアリアスが. 此コト モ. 像メ等速デアルコトフ試驗フ致シマス。 双テ之ア撮影致シマスノニハ先ヅ細イ金屬性ノ 鎖 ヨ鼻底及ビ,舌背上二装置致シマシテ，其墢音 ニ支障ノナイコトア確メテカラ撮影裳ノ上ニ上 リ. 次デ「フィルム」，移動卜「レ」線／故射 ガ始アルト同時ニ「シグナルラムブ」が惩ゼラ レマシテ. 被驗者八之ヨ見テ道チ=例へパ「カ 一」ト云フ風二發音スルノデアリアス。此栐=

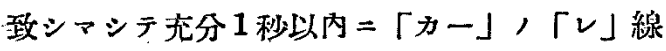
「キモグラム」ガ撮リ終ルノデフリマス。我々 ノ得ヨウト欲スル!八主トシテ軟口蓋及ビ舌背 ノ運動デアリマスルガ. 事實八. 此寫真=見エ マスル運動八夫等ノ上二载セラレタ畬ノ運勘シ カ見ラレナイノデアリマシテ，及例人バ軟口篮 ノ運動ノ如キハ必ズシモ上下，運動バカリデハ アリマセンノデ．と等ノ點二就キ改良スべキ點 ガフルト浩へマス。攵撮影卜同時二例へバ「ト ーキー」ノ如キモノ、同時錄音ヨシタナラバ. 一首正確ナモノニナルデアラウト云フ風二考人 テ居リマスガ. 鬼二伨. 語音調節ノ場合二於々 ル之等ノ部分，動的現像，研究二對シテ一步 7 踏入レルコトガ出來ル/デハナイカト考へテ居 リマスノデ，立三竄真习御目二師ケル次第デア リマス。

\section{9. 氣管枝異物ノ賽驗的研究（第二報）}

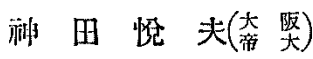

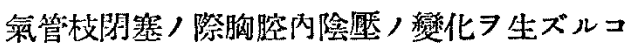
ト八既二實驗的並二䠛林的二證明セラレタル所 シシテ其際胸腔內陰是，變化，描竄八「タンブ 一ル」／膜面ノ移動习疅シメタルモノナリ。余

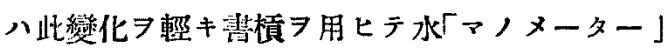

水柱面ノ移動 7 直接烟紙上二描寫セシメ得タル ア以ツテ. 此描竄曲線ノ高サ 72 倍スレハ嘪際 ノ水柱ノ高サトナリ。胸膜似陰壓，量的测定， 谌ダ容易トナレリ。

實驗方法八犬ノ右側ノ主氣管枝 7 異物 7 以テ閶 塞シタル後 24 時間シテ「レ」線寫真ノ检查 行七. 更二異物 左側ノ氣管枝 見. 烟紙上二描寫セシメテ觀察セリ。之二使用 七ル犬八 15 例ニテ以下記载，數字八「ミリメ: ートル」フ單位ト七ル水柱ノ高サニシテ賽驗成 縝八大要次, 如シ。

先ヅ右側主氣管枝閉塞 24 時間後/右側/胸腔 冈陰壓ノ變化 7 見ル二。呼氣時 $=ハ 70 ヨ$ リ 90 迄ノモ/最モ多ク，吸氣時ニハ100ヨリ120迄 ノモノ最多シ，而シテ其呼氣時卜吸氣時卜/差 節千呼吸振幅ハ 6 ヨリ 36 迄ノ小ナルモノト 56 ヨリ 93 迄ノ大ナルモノ 二二分サレ前者八閉塞 完全ニシテ呼氣時院壓モ 70 以上ノモノニ多ク 見ル。次二異物 $尹$ 右側 $コ$ 左側へ詰換へタル時 ノ右ノ胸腔內㓌壓ノ變化 7 見ルニ。其詰メ換一 前二比シ呼氯時陰壓，值ハ殆ンド常二減少シ. 2 時間後, 減少八特二著シク詰メ撸一前ノ約 ${ }^{1 / 2}$ トナルモノアリ。吸氣時陰厴八徐々二堌加スル モノナルモ其度僅少ナり。呼吸振幅八比較的速 $=$ 增州 7 起シ 3 時間後二八約 2 倍. 2 時間後 $=$ 八約 3 倍ヨリ5 倍トナルモノアリ。

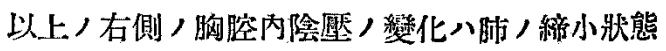
ヨリ快復スル有樣 氣管枝閒塞後呼氣吸氣共 $=$ 陰壓ノ增加 八肺ノ縮小 $=ヨ$ リ肺表面卜胸壁内面卜）間二間

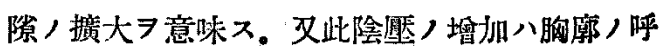

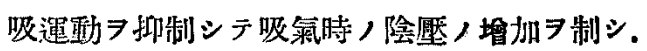




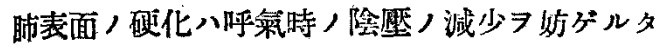
又呼吸振幅入比較的小トナ几所以ナリ。更二異

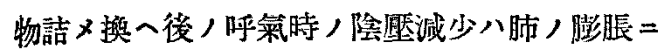
$\exists$ y胸腔間淂ノ縮小 7 意味シ 2 時間後

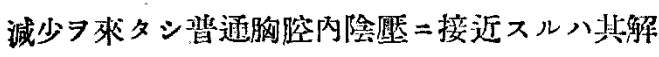
剖的所晃ト一致スル所ナリ。

左側，胸腔内陰厘八右側閉塞，際=モ多少增扠

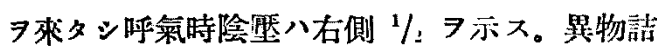

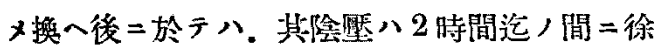

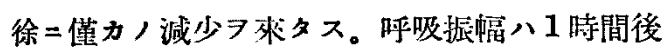
=於テ急二增扣スルモ其後ハ殆ンド變化セス。

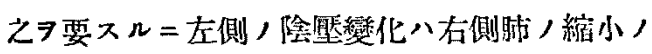

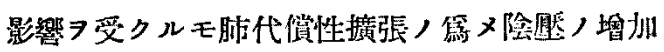

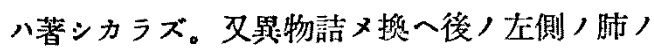
縮小八其度纋慢ニシテ且ツ右側ノ快復速ナルタ

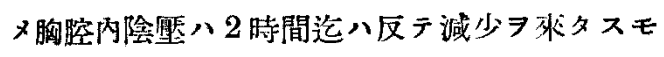
1ナッ。

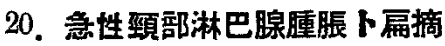

藤 澤 康 武( 和歌哂) 余ハ管性及ビ慢性頸部淋巴㟫腫脹ヨ有スル患 者 ト認メナイ場合トシ問ハズ同側口蓝屚桃㟫/摘 出ヨ行ッテ 乙等淋巴腺腫脹, 治痛經過 $=$ 及ボ ス手石ノ影響フ偗察シテ居タノデアル。

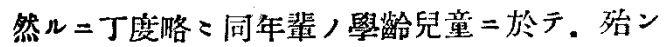

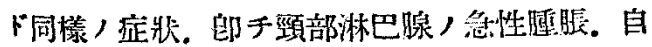
發痛. 嫃度ノ斜頸及ビ發熱ヨ主訴トシ. 或八化 腖=赴クノデハナイカト思ハレタ 3 例ノ念性项 部淋巴腺炎患者二遭遇シタ。其 2 例二八單ニロ 篮扁桃腺，慢性肥大 7 認又。他 1 例二八特别 咽頭所胃八認メラレナカッタノデアルガ 同 側口篮扇桃腺/摘出術 $フ$ 行ツテ

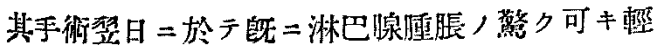

減习認丈。自發㵜モ消失シ。一時八化臊=赴り ノデハナイカト思ハレタ頸部淋巴腺ノ急性腫脹 モ幸ヒ二同側，屚摘術 整二向ツタノデアル。

斯ノ如ク著明ナル急性頸部淋巴腺腄脤例二同側 口蓝局桃腺, 摘出術 得夕報告八未ダ見當ラナイノデ。茲二聊カ其治 惩機轉二就テモ考察》加へ報告シタノデアル。

\section{1. 腹位ニ於ケル会道及ビ氮道直達}

檢查法ノ經驗 牟田哲三郎(大䛀) 大正 11 年 (1922) シュコフ(Shukoff) ガ腹位 ニ於ケル食道及ビ攻道直達检查法提唱以來。吾 國=於テ八检川（大正 15 年) 及ビ㦄森 (昭和 4 年) 等ノ報告アリ。余モ亦炤和 5 年10月大阪地 方會 $=$ 發表七リ。爾來約 8 年斗食道. 唍頭氣

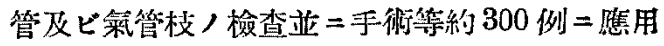
シタル經驗二徴スルニ從来應用七シ坐位. 側位 又八背位等 $=$ 比シ㭧者及ビ沾者共二長時間ノ检

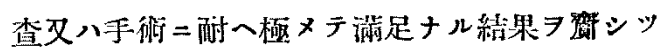

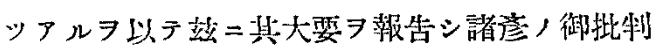
ヨ仰ガントス。

シュコフハ尼艋＝食道鏡又八氮管支鏡 フ雨入シ タル睢之ヨ谏絬鋸斷シテ局所解剖學的检查 $尹$ 行

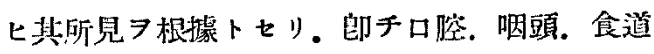
及八氣管ノ各部が一檤線上二來タル要約八主ト

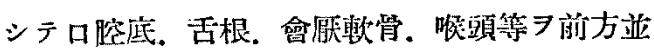

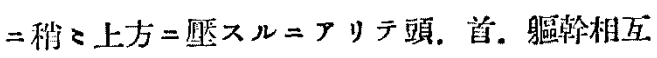

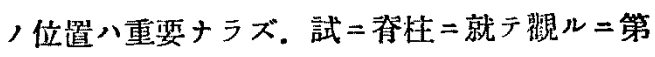
4 愐椎以上八後方二屈曲七ルモ其度八强キ7要 七ズ。第 4 殌椎以下，脊柱八全然然關係ナルコ ト制朋七リ。故二坐位タルト背位タルト二關係 無ク患者八最モ心地良キ位置的于背位及八腹位

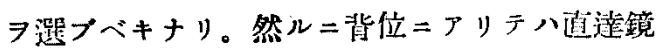

